\title{
Sustainable supply chain management: current debate and future directions
}

\author{
Gestão sustentável de cadeias de suprimento: debate atual e \\ perpectivas futuras
}

\section{Bruno Silvestre ${ }^{1}$}

\begin{abstract}
This paper is a research brief on sustainable supply chain management and covers some of the key elements of literature's past debate and trends for future directions. It highlights the growth of this research area and reinforces the importance of a full consideration of all three key dimensions of sustainability when managing sustainable supply chains, i.e., the financial, environmental and social dimensions. Therefore, supply chain decision makers need to unequivocally assess the impact of their decisions on the financial, environmental and social performances of their supply chains. This paper also argues that risks and opportunities are the key drivers for supply chain decision makers to adopt sustainability within their operations, and that barriers to sustainability adoption exist. This research highlights that, depending on the focus adopted, supply chains can evolve and shift from more traditional to more sustainable approaches over time. The paper concludes with some promising avenues for future investigation.
\end{abstract}

Keywords: Sustainable supply chain; Risks; Opportunities; Barriers; Drivers; Supply chain sustainability trajectory; Contingency approach.

Resumo: Esse artigo é um research brief da literatura de gestão sustentável de cadeias de suprimento, o qual cobre alguns elementos-chave do discurso atual da literatura e das tendências de direções futuras. Este artigo destaca o crescimento desta área de pesquisa e reforça a importância da consideração integral das três dimensões-chave da sustentabilidade dentro das cadeias de suprimento: as dimensões financeira, ambiental e social. Desta forma, tomadores de decisão na cadeia de suprimento precisam avaliar os impactos de suas decisões na performance financeira, ambiental e social de suas cadeias. Este artigo também destaca que os riscos e as oportunidades são os grandes motivadores para que os decisores dentro da cadeia de suprimento adotem o conceito de sustentabilidade em suas operações, e que barreiras à sustentabilidade existem. Essa pesquisa destaca que, dependendo do foco adotado, cadeias de suprimento podem evoluir e mudar de posturas mais tradicionais para posturas mais sustentáveis ao longo do tempo. O artigo conclui destacando algumas áreas promissoras para investigação futura.

Palavras-chave: Cadeia de suprimento sustentável; Riscos; Oportunidades; Barreiras; Motivadores; Trajetória sustentável de cadeias de suprimento; Perspectiva contingencial.

\section{Introduction}

Supply chains are defined as vertical sequences of interdependent transactions that add value to the final consumer (Lee, 2000; Christopher, 2005). The literature on supply chain management has been growing substantially (e.g., Chen \& Paulraj, 2004) and many areas are now at the core of the discussion on the theme such as supply chain integration (e.g., Fawcett, \& Magnan, 2002; Flynn et al., 2010), supply chain collaboration (e.g., Stank et al., 2001; Nagarajan \& Sošić, 2008), supply chain innovation (e.g., Chan \& Qi, 2003; Roy et al., 2004), supply chain sustainability (e.g., Matos \& Hall, 2007, Seuring et al., 2008), supply chain disruptions (e.g., Tang, 2006;
Craighead et al., 2007) and supply chain resilience (e.g., Christopher, \& Peck, 2004; Thomé et al., 2015).

One of the most promising areas within the supply chain literature is the intersection between supply chain management and sustainability (e.g., Clift, 2004). The term sustainability in the business discourse is referred to as the concerns with the Triple Bottom Line (TBL), which includes the need for a simultaneous assessment on the financial, environmental and social dimensions of business operations (Elkington, 1997). Different from the traditional way of doing business, where short-term financial gains have been the only focus at the expense of other "less-important" factors

\footnotetext{
${ }^{1}$ Department of Supply Chain Management, Asper School of Business, University of Manitoba, Drake Centre, 181 Freedman Crescent, Winnipeg, MB, Canada R3T 5V4, e-mail: b.silvestre@umanitoba.ca
} 
(e.g., environmental and social factors), the TBL approach calls for a balance among the financial, the natural environment and the social dimensions when making business decisions.

Based on the TBL approach, research areas related to supply chain management have emerged such as sustainable operations (Kleindorfer et al., 2005; Gimenez et al., 2012), sustainable logistics (Frota et al., 2008; Lee et al., 2010), reverse logistics and closed-loop supply chains (Rogers \& Tibben-Lembke, 2001; Dekker et al., 2013) and sustainable supply chains (Seuring \& Müller, 2008; Linton et al., 2007). Although the sustainability approach has brought significant skepticism among academics, industry and policy makers in the past, the literature has become increasingly more robust. Table 1 shows the number of studies that cite terms related to sustainable supply chain management between 2008 and 2015, and its impressive growth of over $500 \%$. However, some studies argue that research is significantly more prolific on the environmental side while the social side of the TBL still remains neglected (Pullman et al., 2009; Cuthill, 2010; Silvestre, 2015a). This is because many studies focus exclusively on the environmental dimension and ignore the social dimension of business operations (Boström, 2012; Vifell \& Soneryd, 2012), which has given rise to related concepts such as green supply chains and green operations (Zhu \& Sarkis, 2004; Hsu et al., 2013). Although we recognize the importance of these constructs for the evolution of the sustainable supply chain management discourse, in this paper it is argued that these constructs are incomplete because they miss an important part of the puzzle: the social dimension. For example, Hutchins \& Sutherland (2008) argue that social sustainability must be addressed based on four key areas: labour equity, employee healthcare, labour safety and philanthropy. More recently, Carbone et al. (2012) argue that the social performance of supply chains includes working conditions throughout the chain such as salary levels, child labour, work safety, working hours, gender equality, and also product/service safety. The Benoît et al. (2010)'s proposal seems to be more holistic, encompassing several indicators segregated by stakeholder groups. The literature seems to agree that the social dimension should raise significant interest given the fact that a growing number of products, materials and components has been sourced from 'low-cost countries' with inefficient regulatory systems (Ciliberti et al., 2008; Carbone et al., 2012).

In practice, this tendency of seeing "sustainable" as the environmental dimension only is not a privilege from research though. Industry also tends to face the same anomaly and see sustainability only through the lenses of their environmental concerns and initiatives. This tendency disturbs the sustainability discourse and the perception of what sustainability truly is, creating confusing interpretations and misleading impressions that certain supply chains are sustainable, when in reality they are not because the social dimension has not been considered. For example, Lyons et al. (2001) and Colantonio (2009) argue that social sustainability is related to action and policy directed to the promotion of social aspects such as social capital, capability building, empowerment, stakeholders' participation, and livable communities. This research brief argues that studies cannot claim they focus on sustainability, if the social dimension is not being addressed. It is absolutely necessary to focus simultaneously on the three key and interacting dimensions of the TBL in order to say it is truly a sustainability research or initiative.

In Brazil, the area is still in its inception and a few studies are available where the TBL is truly considered on its three key dimensions. For instance, Dias et al. (2012) agree with this overall picture and highlights that while publications on the theme have grown internationally, in the Brazilian journals the numbers are not significant. Brito \& Berardi (2010) state that the literature shows that sustainability initiatives within supply chains are motivated by environmental pressures for minimum standards and

Table 1. Number of articles listed by Google Scholar per term between 2008 and 2015.

\begin{tabular}{cccc}
\hline Year/Term & $\begin{array}{c}\text { Sustainable Supply } \\
\text { Chain }\end{array}$ & $\begin{array}{c}\text { Sustainable Supply Chain } \\
\text { Management }\end{array}$ & $\begin{array}{c}\text { Sustainable Supply } \\
\text { Chains }\end{array}$ \\
\hline $\mathbf{2 0 0 8}$ & 320 & 165 & 116 \\
$\mathbf{2 0 0 9}$ & 411 & 258 & 168 \\
$\mathbf{2 0 1 0}$ & 625 & 407 & 292 \\
$\mathbf{2 0 1 1}$ & 878 & 558 & 426 \\
$\mathbf{2 0 1 2}$ & 1240 & 766 & 565 \\
$\mathbf{2 0 1 3}$ & 1540 & 1030 & 694 \\
$\mathbf{2 0 1 4}$ & 1990 & 1370 & 848 \\
$\mathbf{2 0 1 5}$ & 1990 & 1400 & 880 \\
\hline
\end{tabular}

Source: Google Scholar (2016) search undertaken on 12 of January 2016. 
competitive pressures. Vanalle \& Santos (2014) argue that, based on an empirical study in the automotive sector, in Brazil companies still give low importance to sustainable supply chain initiatives as the traditional environmental measures only (such as reduction of hazardous substances and monitoring/control of effluents) are still the basis for the current dominant approach. Pedroso \& Zwicker (2007) show evidences, based on a successful project in Brazil, that innovation and joint action within supply chains are two of the fundamental drivers for sustainable supply chains.

The operations management literature clearly indicates that an individual organization's sustainable approach would generate real benefit only when it is expanded to its upstream suppliers and downstream buyers (Tang \& Zhou, 2012; Silvestre \& Silva, 2014; Silvestre, 2015a). The literature is also clear that companies that use holistic solutions and work closely with their supply chain partners to manage the trade-offs among the three TBL dimensions are likely to have better business performance (Pope et al., 2005; Matos \& Silvestre, 2013). Since an organization in isolation is very limited in what it can do in practice, consequently sustainability must be associated with the entire supply chain and its secondary stakeholders (e.g., government, NGOs, media, universities), rather than individual parts trying to be more sustainable without any consideration for the whole. This research brief aims to contribute to the sustainable supply chain management discourse by showing that a holistic perspective (i.e., based on the entire supply chain) to sustainability (i.e., based on the TBL) is fundamental when it comes to supply chain sustainability.

\section{Motivations for sustainable supply chain management}

The motivations for supply chains to pursue sustainable operations are driven by two key factors: risks and opportunities. Motivation is a critical factor that impels organizations to pursue certain objectives (Engeström, 2001; Deci \& Ryan, 2000). In the context of supply chains that start sustainability initiatives to pursue more sustainable business practices, motivation is the key indication of why these supply chains focus their energy and money on becoming more sustainable. This discussion is important because the reason why supply chains implement sustainability initiatives and pursue more sustainable business practices vary in terms of the key motivation behind these actions and understanding this "why" question is crucial for the advancement of research and practice of sustainable supply chains.

On one hand, supply chains pursue more sustainable practices because of the risks they may face if they decide not to act. Risks can be associated with for example new and often stricter (in terms of environmental and social performance) government laws and new regulators' policies. This behaviour from governments and regulators can be a product of their own sustainability agenda or a reaction to an external event (e.g., an accident, see Mendes et al., 2014). Risks can also be associated with pressures from secondary stakeholders (e.g., activist groups, NGOs, media, academics) and/or pressures from new sustainability approaches implemented by competing supply chains that may deteriorate a supply chain's competitive advantage.

The supply chain management literature seems to agree that risks are one of the most important management issues that can lead to disruption and other supply chain problems (Christopher \& Lee, 2004). Supply chain risk is related to unforeseen events resulting in negative consequences for a supply chain (Narasimhan \& Talluri, 2009; Hajmohammad $\&$ Vachon, 2016), while supply chain sustainability risk is related to events that can lead to negative social and/or environmental impacts on a supply chain (Blome \& Schoenherr, 2011; Hofmann, et al., 2014). Therefore, risk management seems to be a mandatory activity supply chains must undertake to mitigate such threats (Jüttner et al., 2003). In regards to sustainability, risk management across the entire supply chain allows that environmental and social problems are identified and controlled before they are exposed publicly (Seuring \& Müller, 2008). Consequently, a well-designed risk-oriented supply chain management can put companies in a privileged competitive position (Teuscher et al., 2006). The literature also argues that a proactive approach to sustainability lowers the supply chain risk (Carter $\&$ Rogers, 2008). Risk mitigation strategies focus on reducing the severity of the consequences if an adverse event happens (Manuj \& Mentzer, 2008; Sodhi \& Chopra, 2004; Christopher \& Lee, 2004). However, since some risks are hidden and cannot be identified in advance (Liyanage, 2007), the literature on supply chain resilience suggests that decision-makers should accept that not all hazards and threats can be avoided, controlled, or eliminated (Peck, 2006). Supply chain resilience is the system ability to absorb the impact of the disturbance and get back to the original state as quickly as possible (Christopher \& Peck, 2004; Thomé et al., 2015). Collaboration among supply chain members operating at all supply chain tiers seem to unanimously be on the literature one of the most important drivers for supply chain resilience (Fiksel, 2006; Christopher \& Peck, 2004).

According to the supply chain management literature (Norrman \& Jansson, 2004; Sheffi \& Rice, 2005; Oke \& Gopalakrishnan, 2009), each individual sustainability risk the supply chain faces brings two 
key dimensions that decision makers should consider: the frequency that an event happens and the severity of its consequences. Together they capture "how often" an event can occur (frequency) and "how bad" an event can be in terms of its impacts, damages and detrimental consequences for the supply chain (severity). This research brief puts both dimensions together (see Figure 1) to be able to understand how they jointly impact supply chain management research and practice. The model shows four types of scenarios:

- Type 1: this scenario is associated with events with low frequency and low severity. Supply chains must identify and monitor these risks because these events are rare and insignificant. Therefore supply chains must identify them because they are not frequent and players may not be familiar with them (these risks may be hidden from decision makers), but they are not of concern because they are low severity. However, supply chains need to constantly monitor these risks anyway in order to track for changes in their frequency and/or severity levels.
- Type 2: this scenario is associated with events with high frequency and low severity. Supply chains must monitor and control these risks because these events are frequent, but insignificant. Therefore they are of little concern because they are low severity. However, supply chains need to constantly control these risks anyway in order to keep their severity to the lowest levels possible. Existing data and models may provide the knowledge and mechanisms to address them properly given the fact they are quite frequent (i.e., supply chains are used to deal with them).

- Type 3: this scenario is associated with events with low frequency and high severity. Supply chains must identify and mitigate these risks because these events are not frequent, but associated with high severity consequences. Therefore supply chains must identify them because they are not frequent, i.e., not usual (these risks may be even hidden from decision makers). These risks are of the highest concern because they are of high severity and players may not be familiar with them. Supply chains need to identify them and constantly mitigate

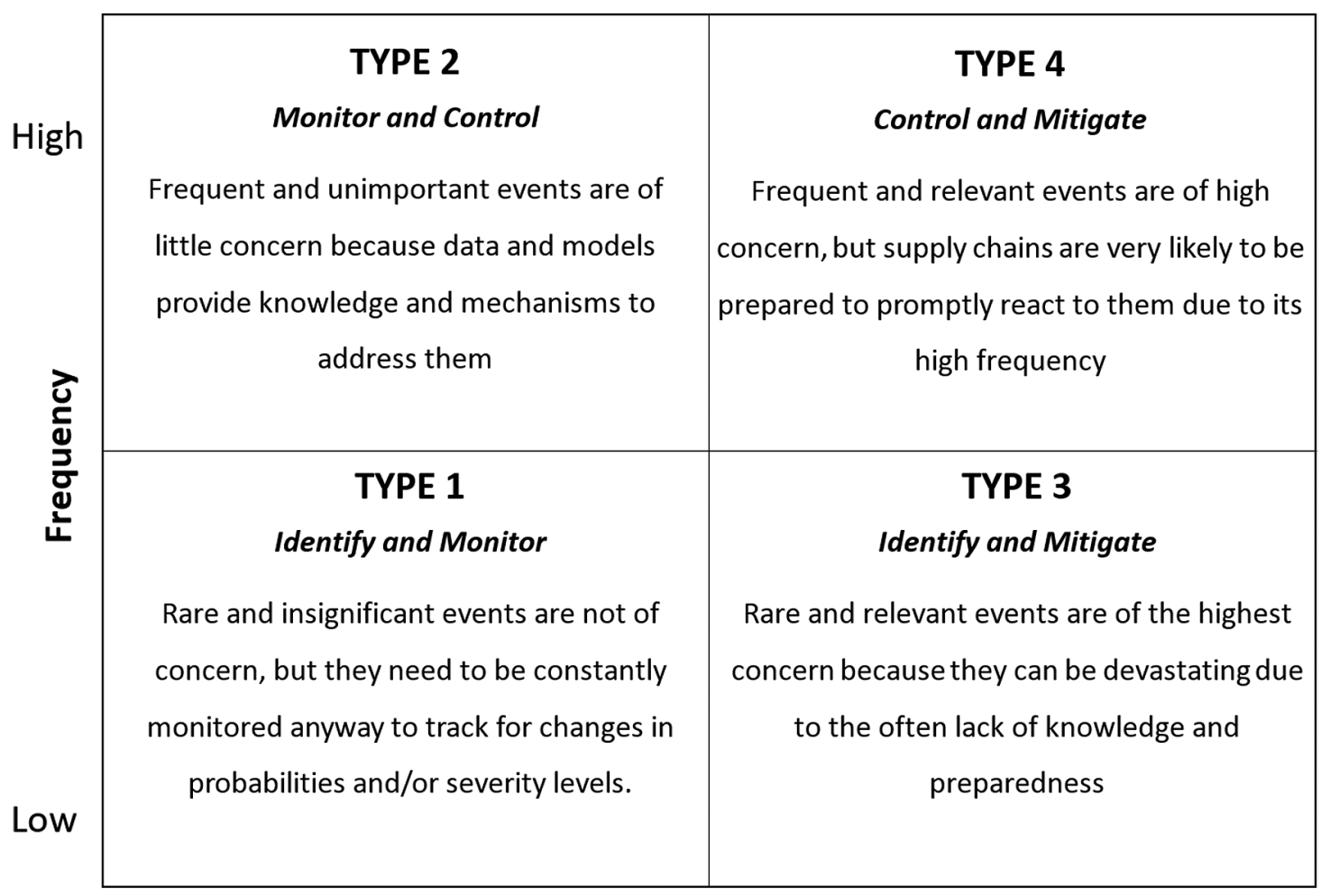 \\ Low Severity

Figure 1. Types of risks that can motivate supply chains to incorporate sustainability. 
these risks to reduce their severity levels if they end up happening.

- Type 4: this scenario is associated with events with high frequency and high severity. Supply chains must control and mitigate these risks because these events are frequent and high severity in terms of their consequences. Therefore these risks are of high concern. Supply chains need to constantly control these risks in order to reduce their frequency and mitigate their severity to the lowest levels possible. Existing data and models may provide the knowledge and mechanisms to address them properly given the fact they are quite frequent (i.e., supply chains are used to deal with them).

On the other hand, supply chains pursue more sustainable practices because they identify business opportunities in the marketplace. Opportunities can trigger the promotion and implementation of sustainability initiatives towards more sustainable practices within supply chains. The literature on supply chain management highlights that opportunities are what lead supply chains to improve, become more sustainable and offer long-term value to all stakeholders (Ballou et al., 2000; Ross, 2013). External and internal factors influence supply chains to pursue new opportunities in the marketplace in order to achieve improved sustainability performance and shape innovative and sustainable business models (Zhu et al., 2008; Walker et al., 2008; Hall et al., 2012; Matos \& Silvestre, 2013). Supply chain opportunities are identified by entrepreneurs who work in organizations operating within a supply chain, the so called intrapreneurs (Pinchot, 1985; Davis, 1999). Analogical reasoning is one of the main mechanisms used by entrepreneurs for opportunity identification and assessment (Holyoak \& Thagard, 1997; Blanchette \& Dunbar, 2000; Jones \& Casulli, 2014). Grégoire \& Shepherd (2012) argue that entrepreneurs can identify opportunities based on two key dimensions of analogy: superficial similarities and structural similarities. Superficial similarity is related to the resemblance between the well-known domain (i.e., related to entrepreneur's past experience) and the new domain (i.e., related to the opportunity identified), while structural similarity is associated with the resemblance in the relationships between the elements of the well-known domain and the relationships between the elements of the new domain (Spellman \& Holyoak, 1996; Keane et al., 1994; Gary et al., 2012). Together superficial and structural similarities will shape how supply chains use analogies to identify, assess and implement opportunities.

Opportunities for supply chains to become more sustainable (i.e., more environmentally and socially friendly) exist (Matos \& Hall, 2007), and recognizing those opportunities can put supply chains in a privileged position to deliver sustainable benefits to all stakeholders (Hall et al., 2012). The literature also argues that a proactive approaches to sustainability opportunity improve supply chain performance (Marshall et al., 2015; Winter \& Knemeyer, 2013). However, information sharing across the supply chain seems to be pointed by the literature as one of the most important drivers for supply chain opportunity identification and realization (Stank et al., 2015; Li et al., 2012; McCarthy et al., 2013).

Supply chain opportunity is related to strategic paths a supply chain is exposed to and that, if identified and assessed properly, can present new and better ways of doing business (Ballou et al., 2000), while supply chain sustainability opportunity is related to opportunities that can lead to an improved social and/or environmental supply chain performance (Linton et al., 2007; Seuring et al., 2008). According to the entrepreneurship literature (Mahnke et al., 2007; Butler et al., 2010; Shepherd \& DeTienne, 2005), each opportunity the supply chain faces brings two key dimensions that decision makers should consider: the uncertainty associated with that opportunity (i.e., how likely the opportunity will unfold itself as expected) and its potential rewards (i.e., how rewarding the opportunity is in terms of its impacts, benefits and consequences). Together they capture "how certain" an opportunity is in terms of its outcomes (uncertainty) and "how good" an opportunity can be (financial and other rewards). We put both dimensions together (see Figure 2) to be able to understand what those dimensions jointly mean in terms of implications for research and practice. The model shows four types of scenarios:

- Type 1: this scenario is associated with opportunities with low uncertainty and low rewards. Supply chains must ignore these opportunities because they are not worth pursuing. Although they are more certain, the potential reward associated with them is also low.

- Type 2: this scenario is associated with opportunities with high uncertainty and low rewards. Supply chains must avoid these opportunities because they are uncertain and insignificant in terms of the potential rewards they offer.

- Type 3: this scenario is associated with opportunities with low uncertainty and high rewards. Supply chains must pursue these opportunities because these events are more certain and the potential reward associated with them is high. Therefore supply chains need to employ strategies to reduce their uncertainties 


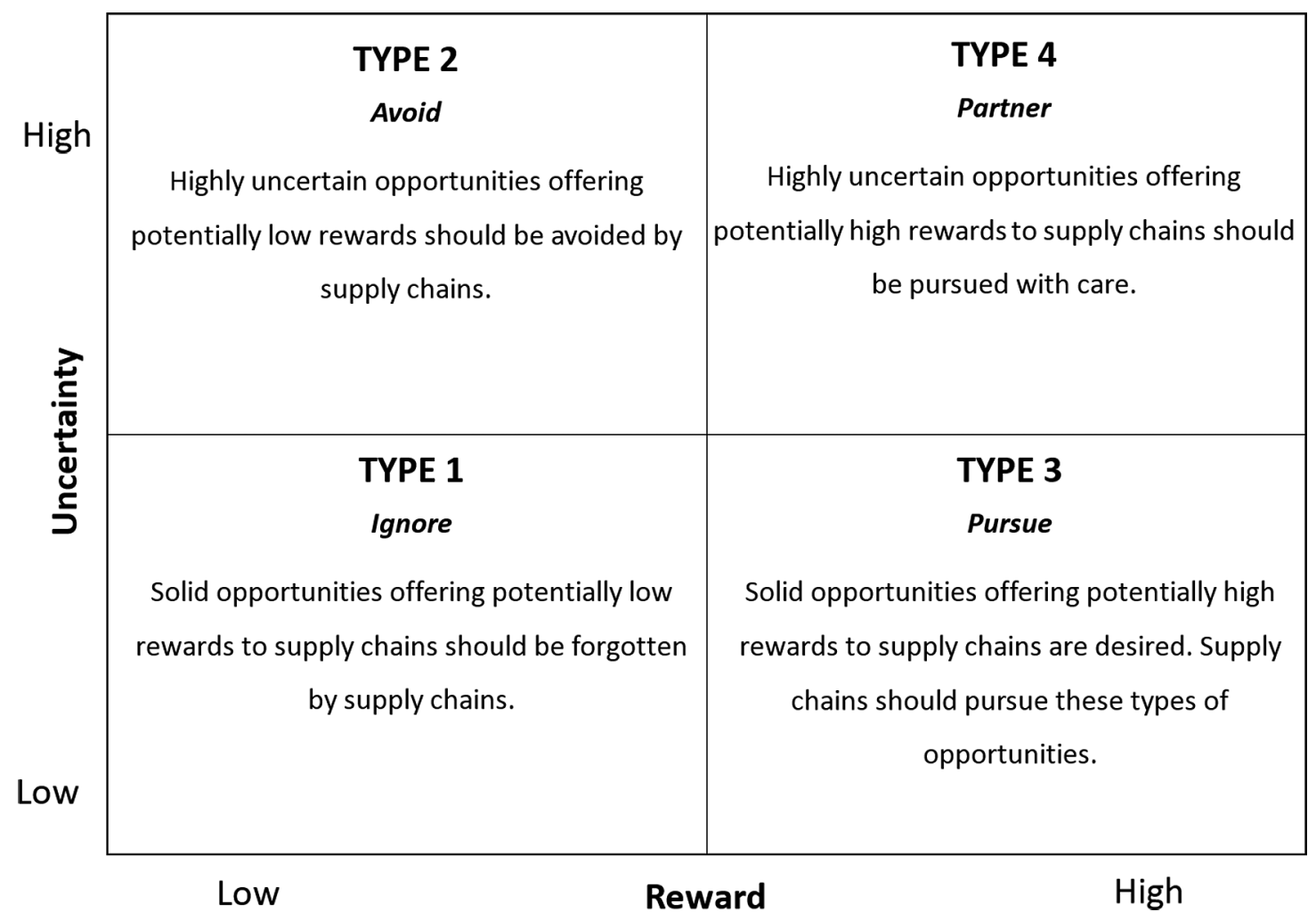

Figure 2. Types of opportunities faced by supply chains.

even further and be prepared to take advantage of the potential rewards associated with them.

- Type 4: this scenario is associated with opportunities with high uncertainty and high rewards. Supply chains must partner with associate organizations and chains (i.e., through joint ventures or other types of partnerships) in order to explore these opportunities further and at the same time isolate the current supply chain operations from the uncertainties these opportunities may present.

Supply chains are different in the way they behave in regards to risks and opportunities. Some supply chains are more prompted to focus on the sustainability risks they are facing and then act accordingly, i.e., engage in a more risk-averse behavior in regards to sustainability. Other supply chains are more motivated to act based on the sustainability opportunities they see for their businesses. i.e., engage in a more opportunityseeking behavior. For example, reactive (risk-averse) supply chains will focus on complying with new sustainability-based (i.e., social and environmental) government regulations or changes on the competition standards, while proactive (opportunity-seeking) supply chains tend to focus not only on compliance, but also on improving their sustainability performance beyond compliance to seize market opportunities (Walton et al., 1998; Hervani et al., 2005). Supply chain proactive approaches to sustainability reduce supply chain sustainability risks (Porter \& Van der Linde, 1995; Carter \& Rogers, 2008), increase supply chain resilience (Craighead et al., 2007; Ponomarov $\&$ Holcomb, 2009) and allow the supply chain to influence and shape its future (Carter \& Dresner, 2001; Silvestre, 2015b).

Besides the key drivers for supply chain sustainability, the literature also claims for further attention to the barriers to sustainability. Barriers to sustainability hinder the ability of supply chains to become more sustainable and can be of diverse nature. For example, Walker \& Jones (2012) segregate the barriers to sustainable supply chains into internal and external, including barriers related to functional issues, strategic issues, people issues, government, consumers and suppliers. Al Zaabi et al. (2013) show evidence in their study that six barriers are more difficult to overcome: cost of sustainability initiatives, lack of sustainability standards and appropriate regulations, misalignment of short-term and long-term strategic goals, lack of effective evaluation measures, inadequate facilities and lack of top management commitment. Silvestre (2015a), in a study focused on the dynamics within emerging economies, highlights four major barriers to supply chain sustainability in these environments: 
corruption, lack of infrastructure, pressing social problems in urban areas, and informality. As pointed out by the author, the corruption barrier was recently observed as the main cause of an unprecedented corruption scandal involving top executives and politicians that hit the Brazilian oil and gas supply chain and its focal company, Petrobras (Romero \& Thomas, 2014; Segal, 2015; Silvestre, 2015a).

\section{A new paradigm for supply chain management}

As implied in the discussion above, the theory and practice of supply chain management have been recently hit by a new emerging paradigm: sustainable supply chain management. This trend is irreversible, but it will take some time until organizations and supply chains can shift from the old traditional paradigm to the new paradigm. The transition is underway and the trend shows evidences that this new paradigm will eventually become dominant not only on the research side but also on the practical side, when firms adopt and make their decisions based on the TBL. When it comes to this sustainability transition, the literature explicitly highlights four types of supply chain approaches in regards to the environmental and social dimensions of supply chain sustainability (see Figure 3).

The traditional way to manage supply chains is to maximize the financial performance and pay little or no attention to supply chain environmental and social performances. This paper classifies these as Efficient Supply Chains (Figure 3). In fact, supply chain financial maximization literature is vast, and examples of supply chain profit maximization studies are everywhere (e.g., Beamon, 1998; Perea-Lopez et al., 2003; Miller \& Matta, 2008). Many supply chain studies reinforce the importance of the financial performance often neglecting the environmental and social performances of their chains. For example, Chen et al. (2013) consider health/hospital supply chain performance from the financial dimension perspective only (i.e., efficiency and cost reduction). Cho et al. (2012) proposes a framework for measuring the performance of service supply chain management exclusively based on efficiency and effectiveness measures and no consideration for the environmental and social dimensions. Other similar studies show the same exclusive attention on the financial dimension (e.g., Lai et al., 2012; Elgazzar et al., 2012). However, these models have been criticized for not considering the environmental or the social dimensions of sustainability (Sen, 1977; Alexander, 2007; Enderle, 2009). For instance, Hall et al. (2012) suggest that supply chains that focus only on financial performance are likely to remain irrelevant, and consequently unsuccessful. Organizations and supply chains are becoming fully aware that an increasing number of opportunities are available outside the traditional short term profit maximization mindset (Chrisman \& Carroll, 1984; Murphy, 2003; Cohen et al., 2008).

\begin{tabular}{|c|c|c|}
\hline High & $\begin{array}{l}\text { Humanitarian SCS } \\
\text { Humanitarian supply chains are related to } \\
\text { approaches where decisions are made based } \\
\text { on social concerns (often besides financial } \\
\text { concerns) }\end{array}$ & $\begin{array}{l}\text { Sustainable SC } \\
\text { Sustainable supply chains are related to the new } \\
\text { business paradigm where decisions are made } \\
\text { based on a balance between financial, } \\
\text { environmental and social concerns }\end{array}$ \\
\hline 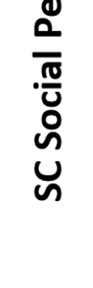 & $\begin{array}{c}\text { Efficient SCS } \\
\text { Efficient supply chains are related to the old } \\
\text { business paradigm where decisions are made } \\
\text { based on exclusively financial concerns }\end{array}$ & $\begin{array}{c}\text { Green SCS } \\
\text { Green supply chains are related to approaches } \\
\text { where decisions are made based on } \\
\text { environmental concerns (often besides the } \\
\text { financial performance) }\end{array}$ \\
\hline \multicolumn{3}{|l|}{ Low } \\
\hline & SC Environme & al Performance \\
\hline
\end{tabular}

Figure 3. Supply chains approaches in regard to the environmental and social dimensions of sustainability. 
The internal and external pressures for environmental performance led theory and practice to coin and implement what we call Green Supply Chains (Figure 3). The term refers to the incorporation of environmental protection principles within the supply chain business practices (e.g., Che, 2010) and it involves evaluating the impact of operations through the entire supply chain and products' life cycles (Handfield et al., 2005; AlKhidir \& Zailani, 2009). Rao \& Holt (2005) and Srivastava (2007) argue that environmental protection principles must be embedded in all activities such as product design, sourcing, manufacturing, warehousing, distributing and end of life product management aspects of a supply chain. For example, Sarkis (2003) argues that increasingly numerous voluntary environmental initiatives are introduced by supply chains. More recently and with an exclusive focus on the environmental dimension (obviously besides the financial dimension), Green et al. (2012) proposes a green supply chain model that incorporates green business practices across the supply chain to support environmental sustainability. Although the environmental dimension becomes central in this type of supply chain approach (besides the financial dimension), the social dimension still does not receive the same level of attention, if any.

Also, external pressures led theory and practice to frame and implement what we call more generally as Humanitarian Supply Chains (Figure 3). This type of supply chains are related to all sorts of social charity, disaster relief and even commercial supply chains. However, one characteristic put all of them together: the focus on the social dimension (besides the financial dimension), and little or no consideration for the environmental dimension. For example, there is a growing literature on humanitarian supply chains, which claims that the purpose of these supply chains is to alleviate the suffering of vulnerable people (Thomas, 2004). Disaster relief supply chains are temporary and associated with the management of aid material, information and service flows directed to reduce the impact of disaster on human lives (John \& Ramesh, 2012). These supply chains must be able to respond to multiple interventions as quickly as possible (Van Wassenhove, 2006; Tomasini \& Van Wassenhove, 2009). Therefore, for disaster relief supply chains, time is an important concern, and it must involve a variety of stakeholders to be able to succeed including donors, humanitarian organizations, NGOs, military, governments, and beneficiaries (Russell, 2005). Social charity supply chains are usually more permanent than disaster relief supply chains, but have the same purpose: the social performance. They often operate to bring supplies (e.g., water, food and medicine) to vulnerable population. Although these supply chains are often not designed to generate profits, cost (which is also related to the financial dimension) is always a key element to be consider. In this regard, Thomas (2004) suggests that effective cost control is crucial for an increased performance of these types of supply chains.

As an evolution of these previous efforts, the term Sustainable Supply Chains have emerged to stay (Figure 3). As implied above, the term is referred to as the one that performs well on both traditional measures of profit and loss as well as on an expanded conceptualization of performance that includes social and natural dimensions (Pagell $\& \mathrm{Wu}, 2009)$. Aligned with the World Commission on Environment and Development (WCED, 1987), Facanha \& Horvath (2005) state that a sustainable supply chain is efficient (i.e., profitable or cost-efficient), effective and meets the needs of the present without comprising the ability of future generations to meet their own needs. Although many decision makers see a trade-off between the financial dimension and the other two key dimensions of the TBL (i.e., environmental and social), recent studies indicate that the implementation of sustainable supply chains actually leads to commercial and financial success in the long run (Zailani et al., 2012).

Studies suggest that supply chains are dynamic entities that evolve over time, and consequently can be seen through the lenses of the evolutionary theory, where they learn, innovate, change and become more sustainable (Silvestre, 2015a). Therefore, supply chains can eventually evolve from one approach to the other (Figure 4). For example, supply chains that use traditional approaches to make decisions (Efficient Supply Chains) can eventually evolve to more sustainable approaches, i.e., to green approaches (Path 1) or sustainable approaches (Path 2) if they manage to incorporate other TBL dimensions of sustainability into their operations. In the same way, supply chains adopting green approaches can eventually evolve to sustainable approaches as they learn, innovate and change toward more socially responsible operations (Path 3). Humanitarians supply chains can also evolve into sustainable approaches as they incorporate the environmental dimension into their decision-making processes (Path 4). Supply chains can also undertake a reverse path as they become less sustainable. These reverse paths may not be typical, but could eventually happen due to for example a specific supply chain event (e.g., an accident or disruption) that forces the supply chain to downgrade or a managerial decision made within the supply chain to deal with a specific circumstance.

\section{Future directions for sustainable supply chain management research}

Base on the discussion above, this research brief delineates four promising avenues for future sustainable supply chain management investigations: 


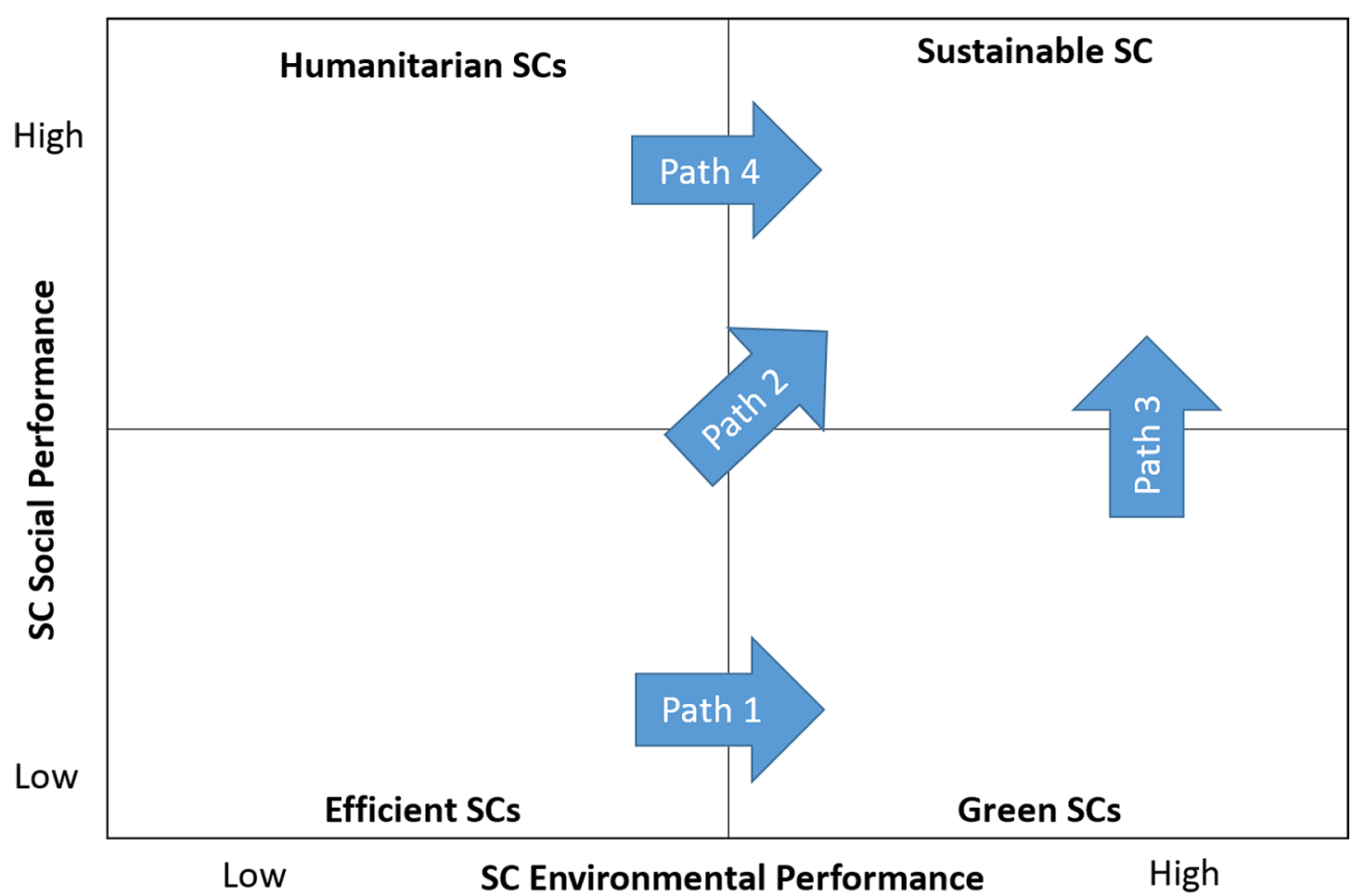

Figure 4. Supply chains paths and trajectories toward more environmentally and socially sustainable approaches.

(i) Sustainable Supply Chain Drivers and Barriers, (ii) Sustainable Supply Chain Genesis, (iii) Sustainable Supply Chains and Innovation, and (iv) Supply Chain Sustainability Trajectories.

Sustainable Supply Chain Drivers and Barriers. Sustainability initiatives are undertaken by supply chains because of the risks and opportunities they face. These are the two main drivers to sustainable supply chains (Ross, 2013; Hajmohammad \& Vachon, 2016). In the opposite direction, the barriers to sustainable supply chains are also key to this research area and are understood to be associated with the supply chain external and internal contexts (Silvestre, 2015a; Walker et al., 2008). However, supply chains are different in what they value, the nature of their operations, target market, etc. Consequently, supply chains are also diverse in terms of the risks, opportunities and barriers they face. This research brief calls for further research on how sustainability risks, opportunities and barriers shape supply chain sustainability efforts in different industries, countries (i.e., developed, emerging and developing economies) and institutional settings. Addressing this gap will allow us to understand why sustainability is initiated (or not) within supply chains operating within different contexts.

Sustainable Supply Chain Genesis. Sustainability initiatives within supply chains are likely to be initiated by pioneer organizations (not necessarily the focal company) and then expanded to the rest of their supply chains. For example, a more proactive organization operating in certain supply chain starts some sustainability initiatives and implements more sustainable practices that will later on be disseminated to other parts of the supply chain. Following the work of Silvestre (2015a), the knowledge dissemination and learning can happen at different pace (e.g., slow or fast). However, this "dissemination" process does not happen automatically. It requires deliberate effort from the disseminator (i.e., the pioneer company that initiated the movement within the supply) and the receptors (i.e., other companies in the supply chains that will later absorb the knowledge and adopt these sustainable practices). This research brief calls for further research on how sustainability initiatives are disseminated across supply chains in different contexts (i.e., developed, emerging and developing economies). It also calls for further investigation on the role played by other elements such as supply chain integration and collaboration. Addressing this gap will allow us to understand how sustainability is disseminated across supply chains. The role of the focal company in this dissemination process is also an area that requires further exploration.

Sustainable Supply Chains and Innovation. Consistent with Pagell \& Wu (2009), this research brief suggests that sustainable supply chains can occur only through learning and innovation. Knowledge accumulated within supply chains allows supply chain members to jointly reduce innovation uncertainties, 
change as a system and become more sustainable (Smith \& Sharicz, 2011; Silvestre, 2015b). Even within contexts with scarce resources innovation can be a driver for supply chain improved sustainability (Calia \& Guerrini, 2006; Silvestre \& Silva, 2014). This research brief calls for further research on how innovations emerge within supply chains in different contexts (i.e., developed, emerging and developing economies). The roles played by focal companies, supply chain integration and collaboration also need further research attention. Addressing these gaps will allow us to understand how and why innovation is connected and triggers sustainability within supply chains.

Supply Chain Sustainability Trajectories. Managing supply chain is a complex task (Choi \& Krause, 2006; Ageron et al., 2012). Supply chains are dynamic systems that evolve towards more sustainable practices through a continuous, evolutionary and multi-direction process of change. In this sense, supply chains are similar to organizations: they are initially immature, but they learn, absorb, and accumulate knowledge and new capabilities over time that allow them to perform new activities, innovate, and develop other capabilities (Nelson \& Winter, 1982; Silvestre \& Dalcol, 2007, 2008, 2009; Hall et al., 2012). Supply chain members jointly learn how to build capabilities for innovations that help the entire supply chain to become more sustainable through learning loops (Silvestre, 2015a). This research brief calls for further research on how supply chains learn, innovate and evolve in their sustainability trajectories, what Silvestre (2015a) framed as the notion of supply chain sustainability trajectories. It also calls for further research on how supply chains undertake the specific paths delineated in Figure 4. Addressing these gaps will allow us to understand how supply chains evolve in their sustainability trajectories overtime and how and at which pace they shift from one approach to the other.

This small list of promising future research areas is neither exhaustive nor exclusive. The literature is growing fast and research opportunities to fill the existing and emerging gaps may arise constantly. The literature seems to agree that sustainable supply chain management research and practice are fundamental and came to stay. However, sustainable supply chain is a relative concept, and this fact may not allow one to conclusively state that a specific supply chain "is" or "is not" sustainable without relying on comparisons against other similar (i.e., within the same sector or industry) supply chains. These comparison should be based on metrics associated with the economic performance, environmental performance and social performance of supply chains as a single system. Also, because of the fact that sustainable supply chain management is based on context-dependent issues, this research brief argues that "one size does not fit all" and calls for contingency approaches, where supply chain sustainability must be assessed and managed on a case by case basis.

\section{Acknowledgements}

The author thanks to the Gestao \& Producao's Editor and Assistant Editor for the opportunity to convey the ideas contained in this research brief. Special thanks go to the Gestao \& Producao's Associated Editor Luiz Felipe Roris Rodriguez Scavarda do Carmo for the invitation to write this paper and for all his support during the article development and publication process.

\section{References}

Ageron, B., Gunasekaran, A., \& Spalanzani, A. (2012). Sustainable supply management: an empirical study. International Journal of Production Economics, 140(1), 168-182. http://dx.doi.org/10.1016/j.ijpe.2011.04.007.

Al Khidir, T., \& Zailani, S. (2009). Going green in supply chain towards environmental sustainability. Global Journal of Environmental Research, 3(3), 246-251.

Al Zaabi, S., Al Dhaheri, N., \& Diabat, A. (2013). Analysis of interaction between the barriers for the implementation of sustainable supply chain management. International Journal of Advanced Manufacturing Technology, 68(1-4), 895-905. http://dx.doi.org/10.1007/s00170-013-4951-8.

Alexander, J. (2007). Environmental sustainability versus profit maximization: overcoming systemic constraints on implementing normatively preferable alternatives. Journal of Business Ethics, 76(2), 155-162. http://dx.doi. org/10.1007/s10551-006-9264-5.

Ballou, R. H., Gilbert, S. M., \& Mukherjee, A. (2000). New managerial challenges from supply chain opportunities. Industrial Marketing Management, 29(1), 7-18. http:// dx.doi.org/10.1016/S0019-8501(99)00107-8.

Beamon, B. M. (1998). Supply chain design and analysis: models and methods. International Journal of Production Economics, 55(3), 281-294. http://dx.doi.org/10.1016/ S0925-5273(98)00079-6.

Benoît, C., Norris, G. A., Valdivia, S., Ciroth, A., Moberg, A., Bos, U., Prakash, S., Ugaya, C., \& Beck, T. (2010). The guidelines for social life cycle assessment of products: just in time! The International Journal of Life Cycle Assessment, 15(2), 156-163. http://dx.doi. org/10.1007/s11367-009-0147-8.

Blanchette, I., \& Dunbar, K. (2000). How analogies are generated: the roles of structural and superficial similarity. Memory \& Cognition, 28(1), 108-124. http://dx.doi. org/10.3758/BF03211580. PMid:10714143.

Blome, C., \& Schoenherr, T. (2011). Supply chain risk management in financial crises: a multiple casestudy approach. International Journal of Production 
Economics, 134(1), 43-57. http://dx.doi.org/10.1016/j. ijpe.2011.01.002.

Boström, M. (2012). A missing pillar? Challenges in theorizing and practicing social sustainability: introduction to the special issue. Sustainability: Science, Practice \& Policy, 8(1), 3-14.

Brito, R. P. D., \& Berardi, P. C. (2010). Competitive advantage and sustainable supply chain management: a meta-analisys. Revista de Administração de Empresas, 50(2), 155-169. http://dx.doi.org/10.1590/S003475902010000200003.

Butler, J. E., Doktor, R., \& Lins, F. A. (2010). Linking international entrepreneurship to uncertainty, opportunity discovery, and cognition. Journal of International Entrepreneurship, 8(2), 121-134. http://dx.doi.org/10.1007/ s10843-010-0054-X.

Calia, R. C., \& Guerrini, F. M. (2006). Estrutura organizacional para a difusão da produção mais limpa: uma contribuição da metodologia seis sigma na constituição de redes intraorganizacionais. Gestão \& Produção, 13(3), 531-543. http://dx.doi.org/10.1590/S0104-530X2006000300014.

Carbone, V., Moatti, V., \& Vinzi, V. E. (2012). Mapping corporate responsibility and sustainable supply chains: an exploratory perspective. Business Strategy and the Environment, 21(7), 475-494. http://dx.doi.org/10.1002/ bse. 1736.

Carter, C. R., \& Dresner, M. (2001). Environmental purchasing and supply management: cross-functional development of grounded theory. The Journal of Supply Chain Management, 37(3), 12-27. http://dx.doi. org/10.1111/j.1745-493X.2001.tb00102.x.

Carter, C. R., \& Rogers, D. S. (2008). A framework of sustainable supply chain management: moving toward new theory. International Journal of Physical Distribution \& Logistics Management, 38(5), 360-387. http://dx.doi. org/10.1108/09600030810882816.

Chan, F. T., \& Qi, H. J. (2003). An innovative performance measurement method for supply chain management. Supply Chain Management: An International Journal, 8(3), 209-223.

Che, Z. H. (2010). Using fuzzy analytic hierarchy process and particle swarm optimisation for balanced and defective supply chain problems considering WEEE/RoHS directives. International Journal of Production Research, 48(11), 3355-3381. http://dx.doi. org/10.1080/00207540802702080.

Chen, D. Q., Preston, D. S., \& Xia, W. (2013). Enhancing hospital supply chain performance: a relational view and empirical test. Journal of Operations Management, 31(6), 391-408. http://dx.doi.org/10.1016/j.jom.2013.07.012.

Chen, I. J., \& Paulraj, A. (2004). Towards a theory of supply chain management: the constructs and measurements. Journal of Operations Management, 22(2), 119-150. http://dx.doi.org/10.1016/j.jom.2003.12.007.
Cho, D. W., Lee, Y. H., Ahn, S. H., \& Hwang, M. K. (2012). A framework for measuring the performance of service supply chain management. Computers \& Industrial Engineering, 62(3), 801-818. http://dx.doi. org/10.1016/j.cie.2011.11.014.

Choi, T. Y., \& Krause, D. R. (2006). The supply base and its complexity: implications for transaction costs, risks, responsiveness, and innovation. Journal of Operations Management, 24(5), 637-652. http://dx.doi.org/10.1016/j. jom.2005.07.002.

Chrisman, J. J., \& Carroll, A. B. (1984). Corporate responsibility: reconciling economic and social goals. Sloan Management Review, 25, 59-65.

Christopher, M. (2005). Logistics and supply chain management. Harlow: Prentice Hall.

Christopher, M., \& Lee, H. (2004). Mitigating supply chain risk through improved confidence. International Journal of Physical Distribution \& Logistics Management, 34(5), 388-396. http://dx.doi.org/10.1108/09600030410545436.

Christopher, M., \& Peck, H. (2004). Building the resilient supply chain. The International Journal of Logistics Management, 15(2), 1-14. http://dx.doi. org/10.1108/09574090410700275.

Ciliberti, F., Pontrandolfo, P., \& Scozzi, B. (2008). Investigating corporate social responsibility in supply chains: a SME perspective. Journal of Cleaner Production, 16(15), 15791588. http://dx.doi.org/10.1016/j.jclepro.2008.04.016.

Clift, R. (2004). Metrics for supply chain sustainability. In S. K. Sikdar, P. Glavic \& R. Jain (Eds.), Technological choices for sustainability (pp. 239-253). Springer Berlin Heidelberg.

Cohen, B., Smith, B., \& Mitchell, R. (2008). Toward a sustainable conceptualization of dependent variables in entrepreneurship research. Business Strategy and the Environment, 17(2), 107-119. http://dx.doi.org/10.1002/ bse. 505 .

Colantonio, A. (2009). Social sustainability: linking research to policy and practice. In Sustainable development: a Challenge for European Research. Oxford: Oxford Brookes University.

Craighead, C. W., Blackhurst, J., Rungtusanatham, M. J., \& Handfield, R. B. (2007). The severity of supply chain disruptions: design characteristics and mitigation capabilities. Decision Sciences, 38(1), 131-156. http:// dx.doi.org/10.1111/j.1540-5915.2007.00151.x.

Cuthill, M. (2010). Strengthening the 'social'in sustainable development: developing a conceptual framework for social sustainability in a rapid urban growth region in Australia. Sustainable Development, 18(6), 362-373. http://dx.doi.org/10.1002/sd.397.

Davis, K. S. (1999). Decision criteria in the evaluation of potential intrapreneurs. Journal of Engineering and Technology Management, 16(3), 295-327. http://dx.doi. org/10.1016/S0923-4748(99)00013-2. 
Deci, E. L., \& Ryan, R. M. (2000). The" what" and" why" of goal pursuits: human needs and the self-determination of behavior. Psychological Inquiry, 11(4), 227-268. http://dx.doi.org/10.1207/S15327965PLI1104_01.

Dekker, R., Fleischmann, M., Inderfurth, K., \& van Wassenhove, L. N. (Eds.). (2013). Reverse logistics: quantitative models for closed-loop supply chains. Berlin: Springer Science \& Business Media.

Dias, S. L. F. G., Labegalinib, L., \& Csillagc, J. M. (2012). Sustentabilidade e cadeia de suprimentos: uma perspectiva comparada de publicações nacionais e internacionais. Produção, 22(3).

Elgazzar, S. H., Tipi, N. S., Hubbard, N. J., \& Leach, D. Z. (2012). Linking supply chain processes' performance to a company's financial strategic objectives. European Journal of Operational Research, 223(1), 276-289. http://dx.doi.org/10.1016/j.ejor.2012.05.043.

Elkington, J. (1997). Cannibals with forks: the triple bottom line of 21st century. Oxford: Capstone.

Enderle, G. (2009). A rich concept of wealth creation beyond profit maximization and adding value. Journal of Business Ethics, 84(3), 281-295. http://dx.doi. org/10.1007/s10551-009-0205-y.

Engeström, Y. (2001). Expansive learning at work: toward an activity theoretical reconceptualization. Journal of Education and Work, 14(1), 133-156. http://dx.doi. org/10.1080/13639080020028747.

Facanha, C., \& Horvath, A. (2005). Environmental assessment of logistics outsourcing. Journal of Management Engineering, 21(1), 27-37. http://dx.doi.org/10.1061/ (ASCE)0742-597X(2005)21:1(27).

Fawcett, S. E., \& Magnan, G. M. (2002). The rhetoric and reality of supply chain integration. International Journal of Physical Distribution \& Logistics Management, 32(5), 339-361. http://dx.doi.org/10.1108/09600030210436222.

Fiksel, J. (2006). Sustainability and resilience: toward a systems approach. Science Practice and Policy, 2(2), 14-21.

Flynn, B. B., Huo, B., \& Zhao, X. (2010). The impact of supply chain integration on performance: a contingency and configuration approach. Journal of Operations Management, 28(1), 58-71. http://dx.doi.org/10.1016/j. jom.2009.06.001.

Frota, J. Q., No., Bloemhof-Ruwaard, J. M., Van Nunen, J. A. E. E., \& Van Heck, E. (2008). Designing and evaluating sustainable logistics networks. International Journal of Production Economics, 111(2), 195-208. http://dx.doi.org/10.1016/j.ijpe.2006.10.014.

Gary, M. S., Wood, R. E., \& Pillinger, T. (2012). Enhancing mental models, analogical transfer, and performance in strategic decision making. Strategic Management Journal, 33(11), 1229-1246. http://dx.doi.org/10.1002/smj.1979.

Gimenez, C., Sierra, V., \& Rodon, J. (2012). Sustainable operations: their impact on the triple bottom line.
International Journal of Production Economics, 140(1), 149-159. http://dx.doi.org/10.1016/j.ijpe.2012.01.035.

Google Scholar. (2016). Retrieved in 2016, on January 12, from http://www.scholar.google.ca/</eref $>$.

Green, K. W. Jr, Zelbst, P. J., Meacham, J., \& Bhadauria, V. S. (2012). Green supply chain management practices: impact on performance. Supply Chain Management: An International Journal, 17(3), 290-305. http://dx.doi. org/10.1108/13598541211227126.

Grégoire, D. A., \& Shepherd, D. A. (2012). Technology-market combinations and the identification of entrepreneurial opportunities: an investigation of the opportunityindividual nexus. Academy of Management Journal, 55(4), 753-785. http://dx.doi.org/10.5465/amj.2011.0126.

Hajmohammad, S., \& Vachon, S. (2016). Mitigation, avoidance, or acceptance? Managing supplier sustainability risk. The Journal of Supply Chain Management, 52(2), 48-65. http://dx.doi.org/10.1111/jscm.12099.

Hall, J., Matos, S., \& Silvestre, B. (2012). Understanding why firms should invest in sustainable supply chains: a complexity approach. International Journal of Production Research, 50(5), 1332-1348. http://dx.doi.org/10.1080 /00207543.2011.571930.

Handfield, R. B., Sroufe, R., \& Walton, S. V. (2005). Integrating environmental management and supply chain strategies. Business Strategy and the Environment, 14(1), 1-19. http://dx.doi.org/10.1002/bse.422.

Hervani, A. A., Helms, M. M., \& Sarkis, J. (2005). Performance measurement for green supply chain management. Benchmarking. International Journal, 12(4), 330-353.

Hofmann, H., Busse, C., Bode, C., \& Henke, M. (2014). Sustainability-related supply chain risks: conceptualization and management. Business Strategy and the Environment, 23(3), 160-172. http://dx.doi.org/10.1002/bse.1778.

Holyoak, K. J., \& Thagard, P. (1997). The analogical mind. The American Psychologist, 52(1), 35-44. http://dx.doi. org/10.1037/0003-066X.52.1.35. PMid:9017931.

Hsu, C. W., Kuo, T. C., Chen, S. H., \& Hu, A. H. (2013). Using DEMATEL to develop a carbon management model of supplier selection in green supply chain management. Journal of Cleaner Production, 56, 164 172. http://dx.doi.org/10.1016/j.jclepro.2011.09.012.

Hutchins, M. J., \& Sutherland, J. W. (2008). An exploration of measures of social sustainability and their application to supply chain decisions. Journal of Cleaner Production, 16(15), 1688-1698. http://dx.doi.org/10.1016/j. jclepro.2008.06.001.

John, L., \& Ramesh, A. (2012). Humanitarian supply chain management in India: a SAP-LAP framework. Journal of Advances in Management Research, 9(2), 217-235. http://dx.doi.org/10.1108/09727981211271968.

Jones, M. V., \& Casulli, L. (2014). International entrepreneurship: exploring the logic and utility of 
individual experience through comparative reasoning approaches. Entrepreneurship Theory and Practice, 38(1), 45-69. http://dx.doi.org/10.1111/etap.12060.

Jüttner, U., Peck, H., \& Christopher, M. (2003). Supply chain risk management: outlining an agenda for future research. International Journal of Logistics: Research and Applications, 6(4), 197-210. http://dx.doi.org/10.1 080/13675560310001627016.

Keane, M. T., Ledgeway, T., \& Duff, S. (1994). Constraints on analogical mapping: a comparison of three models. Cognitive Science, 18(3), 387-438. http://dx.doi. org/10.1207/s15516709cog1803_2.

Kleindorfer, P. R., Singhal, K., \& Wassenhove, L. N. (2005). Sustainable operations management. Production and Operations Management, 14(4), 482-492. http://dx.doi. org/10.1111/j.1937-5956.2005.tb00235.x.

Lai, G., Xiao, W., \& Yang, J. (2012). Supply chain performance under market valuation: an operational approach to restore efficiency. Management Science, 58(10), 1933-1951. http://dx.doi.org/10.1287/mnsc.1120.1523.

Lee, D. H., Dong, M., \& Bian, W. (2010). The design of sustainable logistics network under uncertainty. International Journal of Production Economics, 128(1), 159-166. http://dx.doi.org/10.1016/j.ijpe.2010.06.009.

Lee, H. L. (2000). Creating value through supply chain integration. Supply Chain Management Review, 4(4), 30-40.

Li, X., Goldsby, T. J., Holsapple, C. W., \& Goldsby, M. G. (2012). The effects of entrepreneurial information networks on supply chain alertness and new product development speed. Boca Raton: Association for Small Business and Entrepreneurship.

Linton, J. D., Klassen, R., \& Jayaraman, V. (2007). Sustainable supply chains: an introduction. Journal of Operations Management, 25(6), 1075-1082. http:// dx.doi.org/10.1016/j.jom.2007.01.012.

Liyanage, J. P. (2007). Operations and maintenance performance in production and manufacturing assets: the sustainability perspective. Journal of Manufacturing Technology Management, 18(3), 304-314. http://dx.doi. org/10.1108/17410380710730639.

Lyons, M., Smuts, C., \& Stephens, A. (2001). Participation, empowerment and sustainability: (How) do the links work? Urban Studies, 38(8), 1233-1251. http://dx.doi. org/10.1080/00420980125039.

Mahnke, V., Venzin, M., \& Zahra, S. A. (2007). Governing entrepreneurial opportunity recognition in MNEs: aligning interests and cognition under uncertainty. Journal of Management Studies, 44(7), 1278-1298. http://dx.doi. org/10.1111/j.1467-6486.2007.00730.x.

Manuj, I., \& Mentzer, J. T. (2008). Global supply chain risk management. Journal of Business Logistics, 29(1), 133-155. http://dx.doi.org/10.1002/j.2158-1592.2008. tb00072.x.
Marshall, D., McCarthy, L., McGrath, P., \& Claudy, M. (2015). Going above and beyond: how sustainability culture and entrepreneurial orientation drive social sustainability supply chain practice adoption. Supply Chain Management: An International Journal, 20(4), 434-454. http://dx.doi.org/10.1108/SCM-08-2014-0267.

Matos, S., \& Hall, J. (2007). Integrating sustainable development in the supply chain: the case of life cycle assessment in oil and gas and agricultural biotechnology. Journal of Operations Management, 25(6), 1083-1102. http://dx.doi.org/10.1016/j.jom.2007.01.013.

Matos, S., \& Silvestre, B. S. (2013). Managing stakeholder relations when developing sustainable business models: the case of the Brazilian energy sector. Journal of Cleaner Production, 45, 61-73. http://dx.doi.org/10.1016/j. jclepro.2012.04.023.

McCarthy, I. P., Silvestre, B. S., \& Kietzmann, J. H. (2013). Understanding outsourcing contexts through information asymmetry and capability fit. Production Planning and Control, 24(4-5), 277-283. http://dx.doi.org/10.1080/0 9537287.2011 .648765 .

Mendes, P. A., Hall, J., Matos, S., \& Silvestre, B. (2014). Reforming Brazil' s offshore oil and gas safety regulatory framework: Lessons from Norway, the United Kingdom and the United States. Energy Policy, 74, 443-453. http:// dx.doi.org/10.1016/j.enpol.2014.08.014.

Miller, T., \& Matta, R. D. (2008). A global supply chain profit maximization and transfer pricing model. Journal of Business Logistics, 29(1), 175-199. http://dx.doi. org/10.1002/j.2158-1592.2008.tb00074.x.

Murphy, C. (2003). Special report: the green business revolution: the next big thing. Fortune Small Business, 13, 64-70.

Nagarajan, M., \& Sošić, G. (2008). Game-theoretic analysis of cooperation among supply chain agents: Review and extensions. European Journal of Operational Research, 187(3), 719-745. http://dx.doi.org/10.1016/j. ejor.2006.05.045.

Narasimhan, R., \& Talluri, S. (2009). Perspectives on risk management in supply chains. Journal of Operations Management, 27(2), 114-118. http://dx.doi.org/10.1016/j. jom.2009.02.001.

Nelson, R. R., \& Winter, S. G. (1982). The Schumpeterian tradeoff revisited. The American Economic Review, 72(1), 114-132.

Norrman, A., \& Jansson, U. (2004). Ericsson's proactive supply chain risk management approach after a serious sub-supplier accident. International Journal of Physical Distribution \& Logistics Management, 34(5), 434-456. http://dx.doi.org/10.1108/09600030410545463.

Oke, A., \& Gopalakrishnan, M. (2009). Managing disruptions in supply chains: a case study of a retail supply chain. International Journal of Production Economics, 118(1), 168-174. http://dx.doi.org/10.1016/j.ijpe.2008.08.045. 
Pagell, M., \& Wu, Z. (2009). Building a more complete theory of sustainable supply chain management using case studies of 10 exemplars. The Journal of Supply Chain Management, 45(2), 37-56. http://dx.doi. org/10.1111/j.1745-493X.2009.03162.x.

Peck, H. (2006). Reconciling supply chain vulnerability, risk and supply chain management. International Journal of Logistics: Research and Applications, 9(2), 127-142. http://dx.doi.org/10.1080/13675560600673578.

Pedroso, M. C., \& Zwicker, R. (2007). Sustentabilidade na cadeia reversa de suprimentos: um estudo de caso do Projeto Plasma. Revista de Administração, 42(4), 414-430.

Perea-Lopez, E., Ydstie, B. E., \& Grossmann, I. E. (2003). A model predictive control strategy for supply chain optimization. Computers \& Chemical Engineering, 27(8), 1201-1218. http://dx.doi.org/10.1016/S00981354(03)00047-4.

Pinchot, G., 3rd. (1985). Intrapreneuring: why you don't have to leave the corporation to become an entrepreneur. Champaign: University of Illinois at Urbana-Champaign's Academy for Entrepreneurial Leadership Historical Research Reference in Entrepreneurship.

Ponomarov, S. Y., \& Holcomb, M. C. (2009). Understanding the concept of supply chain resilience. The International Journal of Logistics Management, 20(1), 124-143. http:// dx.doi.org/10.1108/09574090910954873.

Pope, J., Morrison-Saunders, A., \& Annandale, D. (2005). Applying sustainability assessment models. Impact Assessment and Project Appraisal, 23(4), 293-302. http://dx.doi.org/10.3152/147154605781765436.

Porter, M. E., \& Van der Linde, C. (1995). Toward a new conception of the environment-competitiveness relationship. The Journal of Economic Perspectives, 9(4), 97-118. http://dx.doi.org/10.1257/jep.9.4.97.

Pullman, M. E., Maloni, M. J., \& Carter, C. R. (2009). Food for thought: social versus environmental sustainability practices and performance outcomes. The Journal of Supply Chain Management, 45(4), 38-54. http://dx.doi. org/10.1111/j.1745-493X.2009.03175.x.

Rao, P., \& Holt, D. (2005). Do green supply chains lead to competitiveness and economic performance? International Journal of Operations \& Production Management, 25(9), 898-916. http://dx.doi.org/10.1108/01443570510613956.

Rogers, D. S., \& Tibben-Lembke, R. (2001). An examination of reverse logistics practices. Journal of Business Logistics, 22(2), 129-148. http://dx.doi. org/10.1002/j.2158-1592.2001.tb00007.x.

Romero, S., \& Thomas, L. (2014, 15 April). Brazil's star, Petrobras, is hobbled by scandal and stagnation. New York: New York Times.

Ross, D. F. (2013). Competing through supply chain management: creating market-winning strategies through supply chain partnerships. Boston: Springer Science \& Business Media.
Roy, S., Sivakumar, K., \& Wilkinson, I. F. (2004). Innovation generation in supply chain relationships: a conceptual model and research propositions. Journal of the Academy of Marketing Science, 32(1), 61-79. http:// dx.doi.org/10.1177/0092070303255470.

Russell, T. E. (2005). The humanitarian relief supply chain: analysis of the 2004 South East Asia earthquake and tsunami (Doctoral thesis). Massachusetts Institute of Technology, Cambridge.

Sarkis, J. (2003). A strategic decision framework for green supply chain management. Journal of Cleaner Production, 11(4), 397-409. http://dx.doi.org/10.1016/ S0959-6526(02)00062-8.

Segal, D. (2015, 7 August). Petrobras oil scandal leaves brazilians lamenting a lost dream. New York: New York Times.

Sen, A. K. (1977). Rational fools: a critique of the behavioral foundations of economic theory. Philosophy \& Public Affairs, 6, 317-344.

Seuring, S., \& Müller, M. (2008). Core issues in sustainable supply chain management: a Delphi study. Business Strategy and the Environment, 17(8), 455-466. http:// dx.doi.org/10.1002/bse.607.

Seuring, S., Sarkis, J., Müller, M., \& Rao, P. (2008). Sustainability and supply chain management: an introduction to the special issue. Journal of Cleaner Production, 16(15), 1545-1551. http://dx.doi.org/10.1016/j. jclepro.2008.02.002.

Sheffi, Y., \& Rice, J. B., Jr. (2005). A supply chain view of the resilient entreprise. MIT Sloan Management Review, 47(1), 41-48.

Shepherd, D. A., \& DeTienne, D. R. (2005). Prior knowledge, potential financial reward, and opportunity identification. Entrepreneurship Theory and Practice, 29(1), 91-112. http://dx.doi.org/10.1111/j.1540-6520.2005.00071.x.

Silvestre, B. S. (2015a). Sustainable supply chain management in emerging economies: Environmental turbulence, institutional voids and sustainability trajectories. International Journal of Production Economics, 167, 156-169. http://dx.doi.org/10.1016/j.ijpe.2015.05.025.

Silvestre, B. S. (2015b). A hard nut to crack! Implementing supply chain sustainability in an emerging economy. Journal of Cleaner Production, 96, 171-181. http:// dx.doi.org/10.1016/j.jclepro.2014.01.009.

Silvestre, B. S., \& Dalcol, P. R. T. (2007). Conexões de conhecimento e posturas tecnológicas das firmas: evidências da aglomeração industrial de petróleo e gás da Bacia de Campos. Gestão \& Produção, 14(2), 221-238. http://dx.doi.org/10.1590/S0104-530X2007000200003.

Silvestre, B. S., \& Dalcol, P. R. T. (2008). Aglomeração industrial de petróleo e gás da região produtora da Bacia de Campos: sistema de conhecimento, mudanças tecnológicas e inovação. Revista de Administração, 43(1), 84-96. 
Silvestre, B. S., \& Dalcol, P. R. T. (2009). Geographical proximity and innovation: evidences from the Campos Basin oil \& gas industrial agglomeration-Brazil. Technovation, 29(8), 546-561. http://dx.doi.org/10.1016/j. technovation.2009.01.003.

Silvestre, B. S., \& Silva, R., No. (2014). Are cleaner production innovations the solution for small mining operations in poor regions? The case of Padua in Brazil. Journal of Cleaner Production, 84, 809-817. http:// dx.doi.org/10.1016/j.jclepro.2014.01.097.

Smith, P. A., \& Sharicz, C. (2011). The shift needed for sustainability. The Learning Organization, 18(1), 73-86. http://dx.doi.org/10.1108/09696471111096019.

Sodhi, M. S., \& Chopra, S. (2004). Managing risk to avoid supply-chain breakdown. MIT Sloan Management Review, 46(1), 53-61.

Spellman, B. A., \& Holyoak, K. J. (1996). Pragmatics in analogical mapping. Cognitive Psychology, 31(3), 307-346. http://dx.doi.org/10.1006/cogp.1996.0019. PMid:8975685.

Srivastava, S. K. (2007). Green supply-chain management: a state-of-the-art literature review. International Journal of Management Reviews, 9(1), 53-80. http://dx.doi. org/10.1111/j.1468-2370.2007.00202.x.

Stank, T. P., Keller, S. B., \& Daugherty, P. J. (2001). Supply chain collaboration and logistical service performance. Journal of Business Logistics, 22(1), 29-48. http://dx.doi. org/10.1002/j.2158-1592.2001.tb00158.x.

Stank, T., Autry, C., Daugherty, P., \& Closs, D. (2015). Reimagining the 10 megatrends that will revolutionize supply chain logistics. Transportation Journal, 54(1), 7-32. http://dx.doi.org/10.5325/transportationj.54.1.0007.

Tang, C. S. (2006). Robust strategies for mitigating supply chain disruptions. International Journal of Logistics: Research and Applications, 9(1), 33-45. http://dx.doi. org/10.1080/13675560500405584.

Tang, C. S., \& Zhou, S. (2012). Research advances in environmentally and socially sustainable operations. European Journal of Operational Research, 223(3), 585-594. http://dx.doi.org/10.1016/j.ejor.2012.07.030.

Teuscher, P., Grüninger, B., \& Ferdinand, N. (2006). Risk management in sustainable supply chain management (SSCM): lessons learnt from the case of GMO $\square$ free soybeans. Corporate Social Responsibility and Environmental Management, 13(1), 1-10. http://dx.doi. org/10.1002/csr.81.

Thomas, A. (2004). Leveraging private expertise for humanitarian supply chains. Forced Migration Review, 21, 122-144.

Thomé, A. M. T., Scavarda, L. F., Scavarda, A., \& Thomé, F. E. S. S. (2015). Similarities and contrasts of complexity, uncertainty, risks, and resilience in supply chains and temporary multi-organization projects. International Journal of Project Management. http:// dx.doi.org/10.1016/j.ijproman.2015.10.012.
Tomasini, R. M., \& Van Wassenhove, L. N. (2009). From preparedness to partnerships: case study research on humanitarian logistics. International Transactions in Operational Research, 16(5), 549-559. http://dx.doi. org/10.1111/j.1475-3995.2009.00697.x.

Van Wassenhove, L. N. (2006). Humanitarian aid logistics: supply chain management in high gear. The Journal of the Operational Research Society, 57(5), 475-489. http:// dx.doi.org/10.1057/palgrave.jors.2602125.

Vanalle, R. M., \& Santos, L. (2014). Análise das práticas de sustentabilidade utilizadas na gestão da cadeia de suprimentos: pesquisa de campo no setor automotivo brasileiro. Gestão \& Produção, 21(2), 323-339. http:// dx.doi.org/10.1590/0104-530X47613.

Vifell, Å. C., \& Soneryd, L. (2012). Organizing matters: how 'the social dimension' gets lost in sustainability projects. Sustainable Development, 20(1), 18-27. http:// dx.doi.org/10.1002/sd.461.

Walker, H., \& Jones, N. (2012). Sustainable supply chain management across the UK private sector. Supply Chain Management: An International Journal, 17(1), 15-28. http://dx.doi.org/10.1108/13598541211212177.

Walker, H., Di Sisto, L., \& McBain, D. (2008). Drivers and barriers to environmental supply chain management practices: Lessons from the public and private sectors. Journal of Purchasing and Supply Management, 14(1), 69-85. http://dx.doi.org/10.1016/j.pursup.2008.01.007.

Walton, S. V., Handfield, R. B., \& Melnyk, S. A. (1998). The green supply chain: integrating suppliers into environmental management processes. The Journal of Supply Chain Management, 34(1), 2-11.

Winter, M., \& Knemeyer, A. M. (2013). Exploring the integration of sustainability and supply chain management: Current state and opportunities for future inquiry. International Journal of Physical Distribution \& Logistics Management, 43(1), 18-38. http://dx.doi. org/10.1108/09600031311293237.

World Commission on Environment and Development WCED. (1987). Our common future. Oxford: Oxford University Press.

Zailani, S., Jeyaraman, K., Vengadasan, G., \& Premkumar, R. (2012). Sustainable supply chain management in Malaysia: a survey. International Journal of Production Economics, 140(1), 330-340. http://dx.doi.org/10.1016/j. ijpe.2012.02.008.

Zhu, Q., \& Sarkis, J. (2004). Relationships between operational practices and performance among early adopters of green supply chain management practices in Chinese manufacturing enterprises. Journal of Operations Management, 22(3), 265-289. http://dx.doi. org/10.1016/j.jom.2004.01.005.

Zhu, Q., Sarkis, J., \& Lai, K. H. (2008). Confirmation of a measurement model for green supply chain management practices implementation. International Journal of Production Economics, 111(2), 261-273. http://dx.doi. org/10.1016/j.ijpe.2006.11.029. 